\title{
Decolorization of Pulp and Paper Mill Effluents Using Wood Rotting Fungus Fibrodontia sp. RCK783S
}

\author{
Torpong Kreetachat, Onnapha Chaisan, and Pilanee Vaithanomsat
}

\begin{abstract}
This work was conducted to evaluate the decolorization of pulp and paper mill effluents and the production of ligninolytic enzymes by wood rotting fungus Fibrodontia sp. RCK783S. Experimental studies were performed in growth minimal medium. As a result, Laccase activity was the main enzyme involved in decolorization of pulp and paper mill effluents. Optimization of Lac production was carried at $\mathrm{C} / \mathrm{N}$ ratio 15.0 to $25.0, \mathrm{CuSO}_{4}$ of 0.002 to $0.0004 \mathrm{~g} / \mathrm{L}$ and L-asparagine of 1.563 to $2.813 \mathrm{~g} / \mathrm{L}$. It was performed by Central Composite Design (CCD). A total of 20 experiments were carried out and the Lac production of 5,145 unit/L was observed at $\mathrm{C} / \mathrm{N}$ ratio of $18.0, \mathrm{CuSO}_{4} 0.0035 \mathrm{~g} / \mathrm{L}$ and $\mathrm{L}$-asparagine $2.2256 \mathrm{~g} / \mathrm{L}$. In addition, the maximum color and TOC removal efficiency were 61.58 and $48.32 \%$ at 5 days of incubation, respectively.
\end{abstract}

Index Terms-Decolorization, wood rotting fungus, pulp and paper mill wastewater, Fibrodontia sp.

\section{INTRODUCTION}

The effluents from pulp and paper mill conventional biological treatment plant constitute a threat to the environment in water pollution. The degradation products of pulp and paper mill production process are often lignin and its derivatives [1], [2]. The previous studies have shown that many lignin and its derivatives in pulp and paper mill wastewater are not degraded in ordinary biological treatment processes and that they can be discharged from the treatment However, the absorption of light due to lignin creates problems to photosynthetic aquatic plants and algae [3].

The combination of physicochemical treatment (e.g. activated carbon adsorption, advance oxidation process, electrolysis, photo-catalysis and chemical coagulation) has been developed to decolorize pulp and paper mill effluents. However, these integrated treatment methods have limited efficiency such as high amounts of chemical usage and sludge generation, costly infrastructure requirements and high operating expenses [4].

In recent years many researches have demonstrated that several strains of wood rotting fungus are capable of oxidizing the various types of complex structures such as lignin and its derivatives, synthetic textile dyes and aromatics

Manuscript received April 5, 2015; revised June 26, 2015. This work was supported in part by the University of Phayao, Phayao, Thailand (R020058223033).

Torpong Kreetachat and Onnapha Chaisan are with the School of Energy and Environment, University of Phayao, Phayao, 56000 Thailand (e-mail: torpong.kr@up.ac.th, onnapha.ch@up.ac.th).

Pilanee Vaithanomsat is with the Kasetsart Agricultural and Agro-Industrial Product Improvement Institute (KAPI), Kasetsart University, Bangkok, 10900 Thailand (e-mail: p_vaithanomsat@yahoo.com). compounds. The most studied wood rotting fungus is the white-rot fungus Phanerochaete chrysosporium, which is able to decolorize various complex structures. The use of fungus species of the genera Pleurotus, Bjerkandera, Trametes, Polyporus, Aspergillus, Trichoderma, Penicillium and Rhizopus have been also investigated [5], [6]. The non-specific extracellular lignolytic enzymes; laccase, lignin peroxidase and manganese peroxidase are thought to play a major role in these transformations [7], [8].

The present work aimed at using wood rotting fungus strain Fibrodontia sp. RCK783S for decolorization of pulp and paper mill effluents. The treatment efficiency and enzymes activities had been proposed for the studies. The optimum of culture medium was also investigated by statistical technique namely response surface methodology (RSM).

\section{MATERIALS AND METHOD}

\section{A. Microorganism and Enzyme Assay}

The wood rotting fungus strain Fibrodontia sp. RCK783S collected and isolated from natural site in Northern of Thailand [9]. The strain was cultured on potato dextrose agar (PDA). The stock culture was stored at $4{ }^{\circ} \mathrm{C}$ until used and sub-cultured every month. The reagent 2,2-azino-bis(3-ethylbenzthiazoline-sulfonic acid) (ABTS) was used as a substrate for spectrophotometric determination of laccase activity (Lac). Oxidation of ABTS was monitored by following the increase in A420 (coefficient $=36,000 \mathrm{M} / \mathrm{L} . \mathrm{CM}$ ) [10]. One activity unit (U) was the amount of enzyme that oxidized $1 \mu \mathrm{mol}$ of ABTS per min.

\section{B. Culture Media and Growth Conditions}

The liquid medium used for the Lac production was MM gram per liter: glucose 10.0; yeast extract $1.25 ; \mathrm{K}_{2} \mathrm{HPO}_{4} 1.0$; $\mathrm{MgSO}_{4} .7 \mathrm{H}_{2} \mathrm{O} 0.5 ; \mathrm{KCl} 0.5 ; \mathrm{FeSO}_{4} .7 \mathrm{H}_{2} \mathrm{O} 0.1 ; \mathrm{MnSO}_{4} \cdot 4 \mathrm{H}_{2} \mathrm{O}$ $0.008 ; \mathrm{Zn}\left(\mathrm{CH}_{3} \mathrm{COO}\right)_{2} \quad 0.003 ; \mathrm{Ca}\left(\mathrm{NO}_{3}\right)_{2} \cdot 4 \mathrm{H}_{2} \mathrm{O} \quad 0.006$ and $\mathrm{CuSO}_{4} .5 \mathrm{H}_{2} \mathrm{O}$ 0.003; at $\left.\mathrm{pH} 5.5\right)$. The fungal agar disks (diameter of $7.0 \mathrm{~mm}$ and taken from PDA plate) were used for the inoculation. A volume $(100 \mathrm{~mL})$ of medium in $250 \mathrm{~mL}$ Erlenmeyer flasks were sterilized at $121{ }^{\circ} \mathrm{C}$ for $15 \mathrm{~min}$ and incubated with $120 \mathrm{rpm}$ shaking at room temperature $\left(\sim 30^{\circ} \mathrm{C}\right)$. Samples were periodically taken for the analysis of cell dry weight and the activities of Lac and all the experiment was carried out in triplicates.

\section{Experiment Design for Lac Production by RSM}

The RSM was used to find the medium compositions significantly influencing Lac production. Glycerol, $\mathrm{NH}_{4} \mathrm{NO}_{3}$, $\mathrm{CuSO}_{4}$ and L-asparagine are the most significant factors in the intensity of the response to Lac production by Fibrodontia sp. 
RCK783S [9]. In this work, the variable studied were $\mathrm{X}_{1}, \mathrm{C} / \mathrm{N}$ ratio; $\mathrm{X}_{2}, \mathrm{CuSO}_{4} ; \mathrm{X}_{3}$, L-asparagine. In the optimization assays, the effects of factors $\mathrm{X}_{1}, \mathrm{C} / \mathrm{N}$ ratio; $\mathrm{X}_{2}, \mathrm{CuSO}_{4}$ and $\mathrm{X}_{3}$, L-asparagine were significant for Lac production. The ligninolytic enzymes (Lac, LiP and MnP) are produced by white rot fungus during the secondary metabolism under limited nitrogen conditions. The 2 inducer concentration (L-asparagine and $\mathrm{CuSO}_{4}$ ) also improves the ligninolytic enzymes production because of copper plays as a ligninolytic enzymes especially Lac cofactor and it can improve the performance of Lac. A Central Composite Design (CCD), consisting of a 20 experiment set with replicates at central point was conducted (Table I). All experiments were inoculated with 10 corks of Fibrodontia sp. RCK783S and were incubated with $120 \mathrm{rpm}$ shaking at room temperature for 14 days.

TABLE I: EXPERIMENTAL FACTORS AND LEVEL FOR CULTURE MEDIUM OPTIMIZATION BY RSM

\begin{tabular}{|c|c|c|c|c|}
\hline \multirow{2}{*}{ Factor } & \multirow{2}{*}{ Code } & \multicolumn{3}{|c|}{ Coded levels } \\
\hline & & -1 & 0 & 1 \\
\hline $\begin{array}{c}\mathrm{C} / \mathrm{N} \text { ratio } \\
\text { (glycerol/ } / \mathrm{NH}_{4} \mathrm{NO}_{3} \text { ) }\end{array}$ & $\mathrm{X}_{1}$ & 15.0 & 20.0 & 25.0 \\
\hline $\mathrm{CuSO}_{4}(\mathrm{~g} / \mathrm{L})$ & $\mathrm{X}_{2}$ & 0.002 & 0.003 & 0.004 \\
\hline L-asparagine $(\mathrm{g} / \mathrm{L})$ & $X_{3}$ & 1.563 & 2.188 & 2.813 \\
\hline
\end{tabular}

\section{Fungal Treatment of Pulp and Paper Mill Effluents}

The Fibrodontia sp. RCK783S was cultivated as described earlier and the mycelium was collected by filtration under aseptic conditions and washed with $500 \mathrm{~mL}$ of sterilized water. A sample of $1.0 \mathrm{~g}$ (wet weight) of mycelium was incubated for 8 days with pulp and paper mill effluents with $120 \mathrm{rpm}$ shaking at room temperature. The characteristics of the effluents before fungal treatment were followed: $\mathrm{pH}$ ranging 6.77-7.05, TOC ranging 441.2-501.5 mg/L and color ranging 1,375-1,654 Pt/Co Unit. The composition (derived from previous experiment) of the carbon source, nitrogen source and trace element solution per liter was fixed as follows: $\mathrm{C} / \mathrm{N}$ ratio, 18.0; L-asparagine, $2.2256 \mathrm{~g}$ and $\mathrm{CuSO}_{4}, 0.0035 \mathrm{~g}$. The $\mathrm{pH}$ of the culture medium was adjusted to 6.0. Sterile controls without inoculum were also maintained under the same conditions. After interval time $(24 \mathrm{hr})$, the incubation mixtures were filtered using $0.45 \mu \mathrm{m}$ pore size filter paper. The decolorization of pulp and paper mill effluents efficiency was determined spectrophotometrically at $475 \mathrm{~nm}$.

\section{RESULTS AND DISCUSSION}

\section{A. Production of Extracellular Lignolytic Enzymes in Minimal Medium}

The present study represents that Fibrodontia sp. RCK783S was grown in MM at room temperature. The relation between the cell dry weight and extracellular lignolytic enzymes was shown in Fig. 1. The highest enzyme activity was Lac $(1,256.06 \mathrm{Unit} / \mathrm{L})$ on day 9 of incubation, whereas $\mathrm{LiP}$ and $\mathrm{MnP}$ activities were found at low level (less than 7.52 and 187.2 Unit/L, respectively). Asgher et al. (2008) referred to many reports that decolorization of wastewater was carried out by a variety strains of white-rot fungi. In most cases Lac was responsible for color removal [11].

\section{B. Optimization of Lac Activitiy}

The response surface methodology (RSM) allows investigation of interaction between parameters that influence the response of a process significantly. In this study, RSM was used to optimize and understand the relationship between significant culture medium and Lac activity. Fig. 2 and Fig. 3 show the interactive effect of two variables $\mathrm{CuSO}_{4}\left(\mathrm{X}_{2}\right)$ and L-asparagine $\left(\mathrm{X}_{3}\right)$ in the range of 0.002-0.004 and 1.563-2.813 mg/L, respectively. The optimum level of Lac activity production occurred with $5,227 \mathrm{Unit} / \mathrm{L}$ at $\mathrm{CuSO}_{4}$ of 0.0028 and L-asparagine of $2.235 \mathrm{~g} / \mathrm{L}$. Furthermore, the effect of $\mathrm{C} / \mathrm{N}$ ratio $\left(\mathrm{X}_{1}\right)$ and L-asparagine $\left(\mathrm{X}_{3}\right)$ in the range of 15.0-25.0 and 1.568-2.813 g/L, respectively, was also investigated. The optimum level of Lac activity production occurred with $5,116 \mathrm{Unit} / \mathrm{L}$ at $\mathrm{C} / \mathrm{N}$ ratio of 18.1 and $\mathrm{L}$-asparagine of $2.214 \mathrm{~g} / \mathrm{L}$. Finally, the effect of $\mathrm{C} / \mathrm{N}$ ratio $\left(\mathrm{X}_{1}\right)$ and $\mathrm{CuSO}_{4}\left(\mathrm{X}_{2}\right)$ resulted in the optimum level of Lac activity production at 5,016 Unit/L at $\mathrm{C} / \mathrm{N}$ ratio of $17.8 \mathrm{~g} / \mathrm{L}$ and $\mathrm{CuSO}_{4}$ of $0.0028 \mathrm{~g} / \mathrm{L}$.

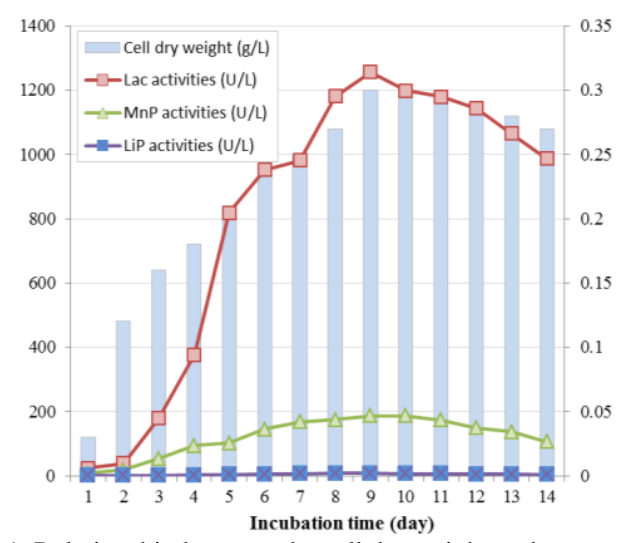

Fig. 1. Relationship between the cell dry weight and extracellular ligninolytic enzymes.

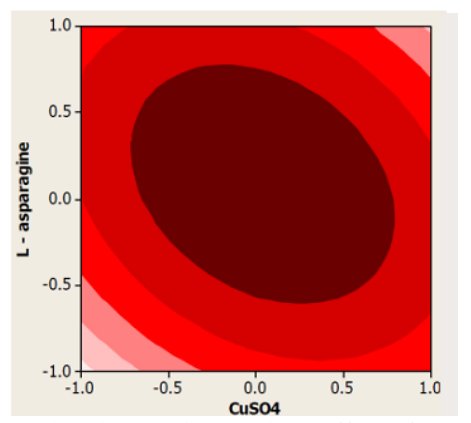

Fig. 2. Contour showing the interactions effect of $\mathrm{CuSO}_{4}\left(\mathrm{X}_{2}\right)$ and L-asparagine $\left(\mathrm{X}_{3}\right)$ on Lac activity production.

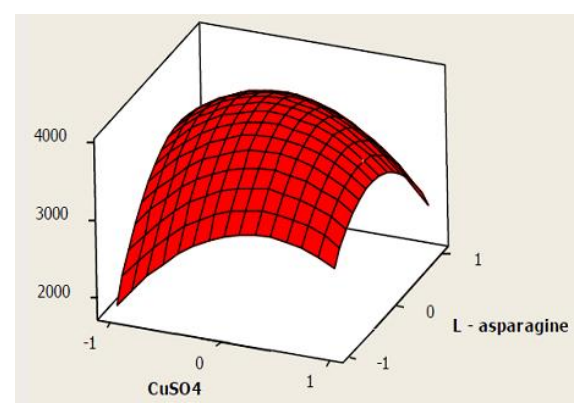

Fig. 3. Surface plot showing the interactions effect of $\mathrm{C} / \mathrm{N}$ ratio $\left(\mathrm{X}_{1}\right)$ and $\mathrm{CuSO}_{4}\left(\mathrm{X}_{2}\right)$ on Lac activity production.

A regression model consisted of three linear term $\left(\mathrm{X}_{1}, \mathrm{X}_{2}\right.$, $\left.\mathrm{X}_{3}\right)$, three quadratic term $\left(\mathrm{X}_{1}^{2}, \mathrm{X}_{2}^{2}, \mathrm{X}_{3}^{2}\right)$ and three 
cross-interactions $\left(\mathrm{X}_{1} \mathrm{X}_{2}, \mathrm{X}_{1} \mathrm{X}_{3}, \mathrm{X}_{2} \mathrm{X}_{3}\right)$ terms plus one block term. Multiple regression analysis was carried out considering full quadratic model on the responses to evaluate the adequacy of fit. The mathematical expression in Lac activity production with variables like $\mathrm{C} / \mathrm{N}$ ratio, $\mathrm{CuSO}_{4}$ and L-asparagine is shown below equation (1):

$$
\begin{aligned}
\text { Lac activity }(\mathrm{Unit} / \mathrm{L})= & 3931.2+344.5 \mathrm{X}_{1}+83.5 \mathrm{X}_{2}+ \\
& 148.6 \mathrm{X}_{3}-773.5 \mathrm{X}_{1}^{2}-651.5 \mathrm{X}_{2}^{2} \\
& +148.6 \mathrm{X}_{3}^{2}+282.375 \mathrm{X}_{1} \mathrm{X}_{2}- \\
& 413.375 \mathrm{X}_{2} \mathrm{X}_{3}+116.375 \mathrm{X}_{1} \mathrm{X}_{3}
\end{aligned}
$$

The $p$-values were employed to evaluate the significance of each coefficient. Smaller $p$-values suggests higher significant of the corresponding coefficient. The $p$-values of constant, $\mathrm{X}_{1}$, $\mathrm{X}_{2}, \mathrm{X}_{3}, \mathrm{X}_{1}^{2}, \mathrm{X}_{2}^{2}, \mathrm{X}_{3}^{2}, \mathrm{X}_{1} \mathrm{X}_{2}, \mathrm{X}_{1} \mathrm{X}_{3}$ and $\mathrm{X}_{2} \mathrm{X}_{3}$ were 0.0012 , $0.0450,0.0088,0.0379,0.0472,0.0500,0.0478,0.0462$, 0.0085 and 0.0495 , respectively. The almost $p$-values were very low $(p<0.05)$, indicating the significance of quadratic equation. From the present study, RSM was applied successfully for the optimization of conditions for Lac activity production. A maximum Lac activity of 5,145 unit/L was observed at $\mathrm{C} / \mathrm{N}$ ratio of $18.0, \mathrm{CuSO}_{4} 0.0035 \mathrm{~g} / \mathrm{L}$ and L-asparagine $2.2256 \mathrm{~g} / \mathrm{L}$.

The experimental results showed the use of statistical optimization tools and response surface methodology (RSM) enables and helps finding the optimum levels of the most significant variables for ligninolytic enzymes production (especially Lac activity) with suitable conditions.

\section{Decolorization of Pulp and Paper Mill Effluents by Fibrodontia sp. RCK783S}

In these experiments, the color and TOC removal efficiencies were analyzed for pulp and paper mill effluents. The experimental results obtained are given in Fig. 4. The trend of treatment efficiencies was with a sharp increase during the first 5 days, after that the treatment efficiencies reached a horizontal limit around 52.2-54.8\% and $38.8-41.2 \%$ for color and TOC removal, respectively. The Lac activity also increased in period of first 5 day incubation, following decreased rapidly after 7 days.

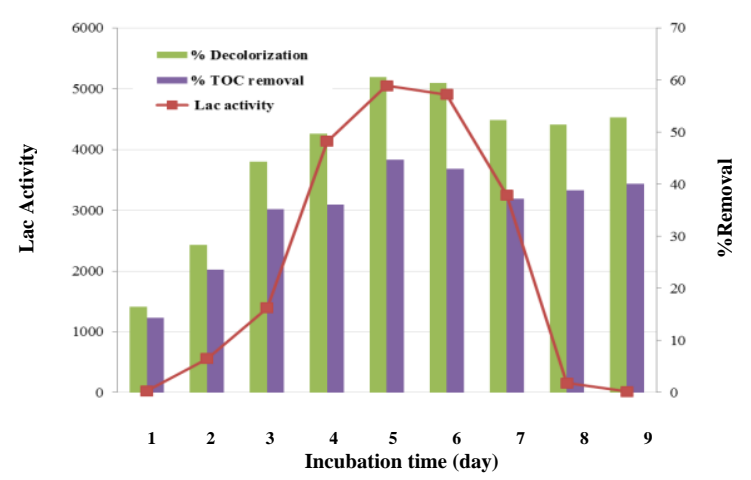

Fig. 4. Relationship between \%color and TOC removal, Lac activity and incubation time.

The color of pulp and paper mill effluents and treated effluents after 5 days by Fibrodontia sp. RCK783S are shown in Fig. 5.

The effect of $\mathrm{pH}$ on decolorization of pulp and paper mill effluents by Fibrodontia sp. RCK783S is shown in Fig. 6. The optimal $\mathrm{pH}$ value for decolorization was determined to be $\mathrm{pH}$ 5.0 , at which $\mathrm{pH}$ the decolorization yield exceeded $50 \%$ after incubation at $25{ }^{\circ} \mathrm{C}$ for 24 hour. However, the temperature variation had little effect on decolorization of pulp and paper mill effluents by Fibrodontia sp. RCK783S below $70^{\circ} \mathrm{C}$, and a maximum decolorization percentage was observed at 50-60 ${ }^{\circ} \mathrm{C}$.

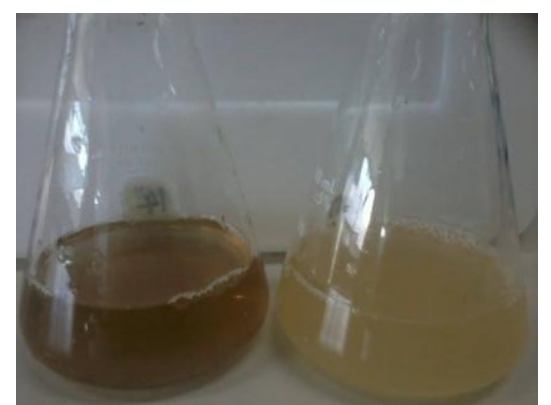

Fig. 5. The color of pulp and paper mill effluents and treated effluents after 5 days treatment by Fibrodontia sp. RCK783S.

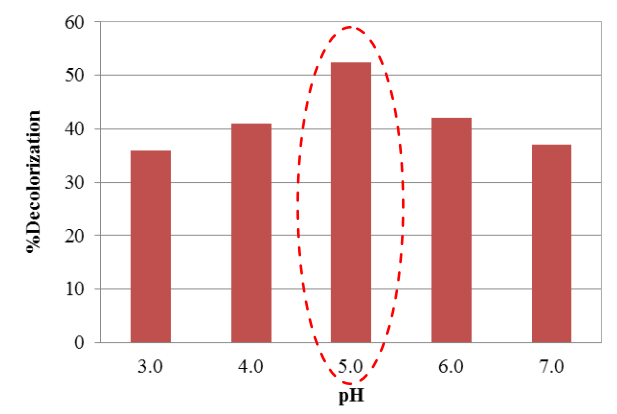

Fig. 6. Effect of $\mathrm{pH}$ on decolorization of pulp and paper mill effluents by Fibrodontia sp. RCK783S.

Yuyi et al. (2011) and Mohamed. E. Osman et al. (2015) reported that the acid conditions could be favorable for the biosorption between the dyes or lignin and its derivatives and the fungal biomass, because a significant high electrostatic attraction could be existed between the positively charged surface of the adsorbent under acidic conditions [12], [13]. For all experimental results found that the $\mathrm{pH}$ and time of incubation were the important parameters for obtaining high decolorization values by Fibrodontia sp. RCK783S.

\section{CONCLUSION}

The isolate of white rot fungus obtained from natural site in Northern of Thailand, Fibrodontia sp. RCK783S was capable of secreting active ligninolytic enzymes and decolorizing the pulp and paper mill effluents. While glucose may be directly added to the wastewater source, it has been found to be more economical to reduce or substantially remove color from the pulp and paper mill effluents by additionally adding Fibrodontia sp. RCK783S in the presence of lignin and its derivatives. The increase of Lac activities, by wood rotting fungus strain Fibrodontia sp. RCK783S, was shown to be correlated with its in vitro decolorization capacity for pulp and paper mill effluents. This enzymatic system appears to be a good candidate for immobilization and used as a bioreactor for pulp and paper mill industries. This study showed the use of statistical optimization tools and response surface 
methodology (RSM) enables and helps finding the optimum levels of the most significant variables for Lac activity with minimum $\mathrm{C} / \mathrm{N}$ ratio, $\mathrm{CuSO}_{4}$ and L-asparagine. By this method, Lac activity as high as 5,145 unit/L after 5 days.

\section{REFERENCES}

[1] D. Pokhrel and T. Viraraghavan, "Treatment of pulp and paper mill wastewater - A review," Sci Total Environ, vol. 333, no. 1-3, pp. $37-58,2004$

[2] T. Kreetachat, M. Damrongsri, V. Punsuwon, P. Vaithanomsat, C. Chiemchaisri, and C. Chomsurin, "Effects of ozonation process on lignin-derived compounds in pulp and paper mill effluents," J Hazard Mater, vol. 142, no. 1-2, pp. 250-257, 2007.

[3] C. Zhang, J. Chen, and Z. Wen, "Alternative policy assessment for water pollution control in China's pulp and paper industry," Resour Conserv Recy, vol. 66, pp. 15-26, 2012.

[4] S. Bayr, P. Kaparaju, and J. Rintala, "Screening pretreatment methods to enhance thermophilic anaerobic digestion of pulp and paper mill wastewater treatment secondary sludge," Chem Eng J, vol. 213, pp. 479-486, 2013.

[5] S. R. Couto and L. T. José, "Laccase production at reactor scale by filamentous fungi," Biotechnol Adv, vol. 25, no. 6, pp. 558-569, 2007.

[6] F. Gassara, S. K. Brar, R. D. Tyagi, M. Verma, and R. Y. Surampalli, "Screening of agro-industrial wastes to produce ligninolytic enzymes by Phanerochaete chrysosporium," Biochem Eng J, vol. 49, no. 3, pp. 388-394, 2010

[7] G. Schober and W. Trösch, "Degradation of digestion residues by lignolytic fungi," Water Res, vol. 34, no. 13, pp. 3424-3430, 2000.

[8] S. Singh and K. Pakshirajan, "Enzyme activities and decolourization of single and mixed azo dyes by the white-rot fungus Phanerochaete chrysosporium," Int Biodeter Biodegr, vol. 64, no. 2, pp. 146-150, 2010.

[9] P. Vaithanomsat, A. Sangnam, T. Boonpratuang, R. Choetklin, P. Promkiam-on, S. Chuntranulack, and T. Kreetachat, "Wood degradation and optimized laccase production by resupinate white-rot fungi in northern thailand," Bioresources, vol. 8, no. 4, pp. 6342-6360, 2013.

[10] C. Eggert, U. Temp, and K. E. L. Eriksson, "Laccase-producting white-rot fungus lacking lignin peroxidase and manganese peroxidase: Role of laccase in lignin biodegradation," Acs Sym Ser, vol. 655, pp. 130-150, 1996

[11] M. Asgher, H. N. Bhatti, M. Ashraf, and R. L Legge, "Recent developments in biodegradation of industrial pollutants by white rot fungi and their enzyme system," Biodegradation, vol. 19, no. 5, pp. 771-783, 2008

[12] Y. Yuyi, W. Guan, W. Bing, L. Zeli, J. Xiaoming, Z. Qifa, and Z. Yuhua, "Biosorption of acid black 172 and congo red from aqueous solution by nonviable penicillium YW 01: Kinetic study, equilibrium isotherm and artificial neural network modeling," Bioresource Tech, vol. 102, pp. 828-834, 2011.

[13] M. E. Osman, O.-K. H. Khattab, A. A. Aoad, and S. A. Ali, "Optimization of different parameters for decolorization of acid black 194 dye using the selected fungal species," Int. J. Curr. Microbiol. App. Sci, vol. 4, no. 3, pp. 866-891, 2015.

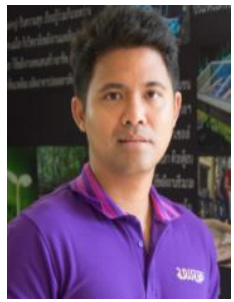

Torpong Kreetachat was born in October, 1978 in Thailand. $\mathrm{He}$ is working in environmental and wastewater engineering for more than 10 years. $\mathrm{He}$ received his Ph.D. degree from Faculty of Engineering, Kasetsart University in 2009.

Dr. Torpong K. is currently an assistant professor in environmental engineering, School of Energy and Environment, University of Phayao (SEEN, UP). He works in a field of advanced oxidation processes (AOPs) in wastewater treatment plant, adsorption technologies, bio-technology for environment, lca. His researches have been published more than 20 papers in several nation and international journals of repute including Journal of Harzadous Materials, Journal of Environmental Biology, Bioresourch etc.

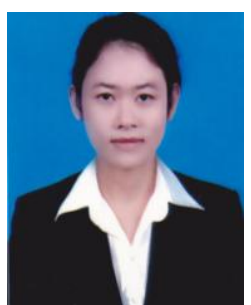

Onnapha Chaisan was born in August 1989. She received her undergraduate degree in microbiology from the Faculty of Medical Sciences at University of Phayao in 2011. She is studying her master degree (M.Eng.) in environmental engineering major at School of Energy and Environment, University of Phayao (SEEN, UP), Thailand where she is a researcher of wastewater engineering laboratory. Her research spans are biological wastewater treatment and industrial pollution control.

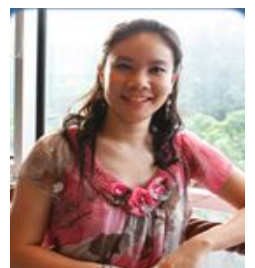

Pilanee Vaithanomsat was born in November 1973 in Thailand. She is working in enzyme technology and harzadous waste for more than 20 years. She received her Ph.D. degree from the Department of Biochemistry, Imperial College of Science, Technology and Medecine University of London in 2000 .

Dr. Pilanee V. is currently an resercher in Kasetsart Agricultural and Agro-Industrial Product Improvement Institute (KAPI), Kasetsart University. She works in a field of biomass utilization, production of enzyme for industrial, bio-technology for environment. Her researches have been published more than 30 papers in several international journals of repute including Journal of Harzadous Materials, Journal of Environmental Biology, Bioresourch etc. 